Article

\title{
In Search of Territorial Cohesion: An Elusive and Imagined Notion
}

\author{
Rob Atkinson ${ }^{1}$ and Carolina Pacchi ${ }^{2, *}$ \\ ${ }^{1}$ Department of Geography and Environmental Management, University of the West of England, Bristol, BS19 1QY, UK; \\ E-Mail: rob.atkinson@uwe.ac.uk \\ ${ }^{2}$ Department of Architecture and Urban Studies, Politecnico di Milano, 20133 Milan, Italy; E-Mail: carolina.pacchi@polimi.it \\ * Corresponding author
}

Submitted: 18 June 2020 | Accepted: 31 August 2020 | Published: 3 December 2020

\begin{abstract}
Territorial cohesion has figured in the lexicon of the European Union for some years. However, there has never been a clear definition of the notion, not even after its inclusion in the Lisbon Treaty. Moreover, within the European Union Cohesion Reports and, more generally, within European Union documents, along with the other two dimensions of cohesion (economic and social) it has been treated separately without any serious attempts to reconcile them and develop a coherent interpretation of cohesion - the result being the creation of a contested and ill-defined understanding of territorial cohesion and its relationship to the other two dimensions of Cohesion Policy. Given that the approach advocated by Directorate-General for Regional and Urban Policy aims to embed the different dimensions and how they interact in specific spatial configurations (created by the confluence of a range of different 'flows' that can create multiple overlapping assemblages with 'fuzzy' boundaries), this raises important questions about how we understand these relationships. Moreover, the policy discourses in which each dimension of cohesion is situated create their own frameworks that are conducive to developing the conditions, including appropriate policy strategies, to supporting these individual cohesion formations. The rather arbitrary separation of these approaches in 'official discourse' impedes addressing cohesion in a coherent and integrated manner. Thus, after reviewing the relevant key policy literature, the article will seek to consider how territorial cohesion relates to the other two dimensions of cohesion taking into account the role of the place-based approach. However, it is argued that the search for territorial (social and economic) cohesion has been subordinated to neoliberal notions such as competitiveness and economic growth.
\end{abstract}

\section{Keywords}

place-based policy; social cohesion; spatial planning; territorial cohesion

\section{Issue}

This article is part of the issue "Cohesion in the Local Context: Reconciling the Territorial, Economic and Social Dimensions," edited by Anja Jørgensen (Aalborg University, Denmark), Mia Arp Fallov (Aalborg University, Denmark), Rikke Skovgaard Nielsen (Aalborg University, Denmark), Hans Thor Andersen (Aalborg University, Denmark) and Maja de Neergaard (Aalborg University, Denmark).

(C) 2020 by the authors; licensee Cogitatio (Lisbon, Portugal). This article is licensed under a Creative Commons Attribution 4.0 International License (CC BY).

\section{Introduction}

A number of key notions have played a key role in the official discourse of and debates around cohesion in the European Union over the last three decades. Initially the main focus was on economic and social cohesion which were incorporated into the Treaty Establishing the European Community by the Treaty of Maastricht in 1992. More informally territorial cohesion was fre- quently linked to economic and social cohesion, in a sense they formed a 'triumvirate' representing the multiple, interlinked, dimensions of cohesion. However, territorial cohesion remained the 'poor relation' of the three in the sense that it lay outside the competence of the European Union because it was not included in the Treaty Establishing the European Community. Thus, whilst present in the debate it was simultaneously officially 'absent.' This 'absence' was finally rectified when it 
was included alongside economic and social cohesion in Article 174 of the 2009 Treaty on the Functioning of the European Union. Article 174 states: "In order to promote its overall harmonious development, the Union shall develop and pursue its actions leading to the strengthening of its economic, social and territorial cohesion" (Treaty on the Functioning of the European Union, 2012). Thus, in the official discourse of the European Union the three are presented together, not in isolation, the clear implication being that they are indivisible. Cohesion Policy and the associated structural funds have been the main vehicle through which the three have been pursued. However, in policy terms, the three have tended to be treated in isolation with economic cohesion tending to dominate through the use of metaphors such as competitiveness and smart growth. In a sense there has been an unwillingness, or perhaps an inability, to develop policies that integrate the three dimensions of cohesion.

This is not just a problem related to Cohesion Policy but also to the wider range of European Union policies developed by the different Directorate Generals of the European Commission. These have tended to be 'blind' vis-à-vis their territorial implications and impacts (cf. Colomb \& Santinha, 2014)-they are 'space blind.' Although it is also fair to say they do not consider the wider social implications of these policies. Arguably this assemblage of disaggregated policies has equally, if not greater, territorial (social and economic) impacts than Cohesion Policy. The overall point being that there has been a persistent inability, or lack of will, to develop policy approaches that simultaneously address economic, social and territorial cohesion as an indivisible trinity. Thus, there is an inherent ambiguity/dissonance in the official discourse of the European Union both specifically in relation to Cohesion Policy and more generally. In part this derives from the political/normative nature of territorial cohesion and its association with the other two dimensions of cohesion. This entails a particular programmatic understanding of 'what the European Union and its constituent space' should be like in terms of its organisational and relational structure. One that is not necessarily shared widely within either the European Commission or European Union in general or by member states.

Whilst it is relatively easy to criticise politicians and policy makers for failing to bring together the three dimensions the academic debate has not been any more successful in attempts to understand their interrelationship and how to develop a coherent understanding of the three dimensions in toto. Arguably one cannot even find a coherent and widely shared understanding of what territorial cohesion means in a conceptual sense in the academic literature. The academic discourse abounds with attempts to define the concept and the relationship between the three dimensions of cohesion (cf. Medeiros, 2016; Mirwaldt, McMaster, \& Bachtler, 2009; Zaucha, 2015). In part this has its origins in different disciplinary approaches to the issue which tend to stress particular aspects whether it be space, policy integration, governance, etc. However, it is also a product of the fact that territorial cohesion is irrevocably entangled with a series of other concepts such as polycentricity, balanced development and (territorial) governance. As we will discuss below each of these concepts and their implications are contested in theoretical, policy and political terms. Thus, it is not simply a matter of coming to a common understanding of territorial cohesion but also of these other concepts and their interrelationships. Moreover, it has often proved difficult to disentangle the theoretical and policy discourses and the normative aspects associated with the political ambitions of the European Integration Project. Cohesion Policy, and the associated structural funds, is perhaps the best example of this. The ultimate aim being to bring all parts of the European Union up to the same level of territorial, economic and social development and provide the framework with which ever closer political integration can take place.

The issues outlined above are further complicated by how they all relate to spatial planning (or spatial development as it is now called; cf. Atkinson \& Zimmermann, 2018), for which the European Union has no legal competence, but which has come to occupy an increasingly prominent position in debates about Cohesion Policy since the publication of the European Spatial Development Perspective in 1999 (Committee on Spatial Development, 1999). The document has influenced the development of structural funds - particularly the European Regional Development Fund-and is a key structuring factor vis-à-vis territorial cohesion.

In the remainder of this article we first of all discuss the evolution of discourse on the different dimensions of territorial cohesion through an analysis of European Union policy documents and academic literature. We then go on to consider the role of spatial configurations at different scales including issues such as polycentricity, urban-rural relations and infrastructure networks. This also entails a reflection on the spatial consequences of economic and social cohesion at different scales. In Section 4 we seek to bring together the intersections/overlaps between the three dimensions of cohesion and the uncertainties and indeterminacy this creates for policy makers and those implementing policy, discussing the case of the Inner Areas Strategy in Italy to highlight the trade-offs between the dimensions and to illustrate the attendant choices and dilemmas. Finally, in the conclusion we will reflect on the on the implications of these developments for territorial cohesion and its relationship to competitiveness and economic growth.

\section{The Evolution of Discourse on the Different Dimensions of Territorial Cohesion}

In order to develop this analysis of the relevant discourse(s) we focus on a series of key documents related to our chosen object of analysis. Here we broadly draw on the work of Atkinson (1999, 2000), which is based 
primarily on a Foucauldian approach. Essentially we use discourse here to refer to "a group of statements which provide a language for talking about a way of representing the knowledge about a particular topic at a particular historical moment. Discourse is about the production of knowledge through language" (Hall, 1997, p. 44). It operates as a 'framing device' seeking to set the terms and limits of the debate. Moreover, like Radaelli (2004) we recognise that discourses are not simply about ideas and language but that they are embedded in institutional contexts and involve interaction and that these interactions in turn shape and reshape the discourse.

In terms of the policy discourse territorial cohesion has implicitly featured in the debate for some years. In part this goes back to the European Spatial Development Perspective (1999), although the term territorial cohesion is only used once in the document. Nevertheless, the terms territory and spatial figure frequently and the ways in which they are deployed can reasonably be interpreted as proxies for territorial cohesion, particularly given their articulation with notions such as polycentricity and balanced development across the European space. The clear implication is that the European space should achieve economic, social and territorial cohesion. Moreover, the argument is that this state of affairs should also be achieved within countries. In many ways the European Spatial Development Perspective established the parameters for the subsequent policy and academic discourses, it identifies three key objectives: 1) economic and social cohesion; 2) conservation of natural resources and cultural heritage (i.e., sustainable development); and 3) more balanced competitiveness of the European territory (Committee on Spatial Development, 1999, p. 10) which are to be pursued in an integrated manner with consideration of how they interact. The attendant modus operandi is one of balanced and polycentric development within a framework of competition and cooperation.

The problem with the European Spatial Development Perspective was its intergovernmental status, this means that it was not an official European Union document (see Atkinson, 2001). Nevertheless, it did exercise considerable influence over the allocation of the structural funds and Cohesion Policy. Moreover, one can find explicit reference to it in the Third Progress Report on Cohesion (Commission of the European Communities, 2005) where in relation to the use of structural funds in new member states it is stated: "Rural policies pursue territorial cohesion objectives and the Lisbon goals" (Commission of the European Communities, 2005, p. 9). The reference here is to the European Agricultural Fund for Rural Development, which is one of the European Union's structural investment funds that collectively contribute to Cohesion Policy in a variety ways. However, no definition of the term is provided.

Its inclusion in the Treaty on the Functioning of the European Union (2009) changed the terms of the discourse in that it was now an official object of policy along with economic and social cohesion. A 'policy definition' of territorial cohesion can be found in the Green Paper on Territorial Cohesion (Commission of the European Communities, 2008):

Territorial cohesion is about ensuring the harmonious development of all these places and about making sure that their citizens are able to make the most of inherent features of these territories. As such, it is a means of transforming diversity into an asset that contributes to sustainable development of the entire European Union. (p. 4)

Here the term is linked to a particular notion of development and in particular what was to become known as the 'place-based approach' (Barca, 2009).

The Green Paper (Commission of the European Communities, 2008) and the associated place-based approach represented a significant step forward in the development of an approach that sought to bring together the territorial, social and economic dimensions, arguing that they cannot be considered in isolation and that, as a result, policies must be developed in an integrated manner and directed at 'meaningful places of intervention' (i.e., not limited by administrative boundaries/borders). This approach has become central to territorial Cohesion Policy as articulated through European Union Cohesion Policy, presenting a way of bringing together economic, social and territorial cohesion in specific places and building a more territorially cohesive and economically balanced European space.

Nevertheless, more recent Cohesion Reports have shied away from an explicit discussion of the notion and its relationship with economic and social cohesion. For instance the Seventh Report on Economic, Social and Territorial Cohesion (Commission of the European Communities, 2017) treats the three separately and the chapter on territorial cohesion "covers the major environmental challenges affecting the development of European Union regions, on the one hand, and a number of major issues addressed by various territorial cooperation schemes, on the other" (Commission of the European Communities, 2017, p. 96).

The Territorial Agenda of the European Union (2007) is more explicit in the way in which it addresses the issue arguing "We see the future task 'Territorial Cohesion' as a permanent and cooperative process involving the various actors and stakeholders of territorial development at political, administrative and technical levels." (Territorial Agenda of the European Union, 2007, p. 1). However, this largely reduces it to an issue of governance. The Territorial Agenda of the European Union 2020 (Territorial Agenda of the European Union, 2011) treats it in a similar manner. While the more recent Territorial Agenda 2020 Put in Practice (2015) argues:

The objective of the TA2020 [Territorial Agenda 2020] is to provide strategic orientations for territorial devel- 
opment, promoting place-based policy making within different policies at all government levels and to ensure implementation of the Europe 2020 Strategy according to territorial cohesion principles which call for a harmonious, balanced, efficient, sustainable territorial development. (p. 5)

It is articulated with notions such as polycentric and balanced territorial development, integrated development in cities, rural and specific regions, global competitiveness of the regions based on strong local economies, etc. But once again there is no clear definition of the notion in policy terms. Furthermore, the Territorial Agenda in its various iterations is once again an intergovernmental document with no official status within the European Union.

If the policy discourse has not provided a clear definition of the term the academic discourse has had no more success. For instance, if we take two examples provided by Mirwaldt et al. (2009) and Medeiros (2016) they note there are numerous understandings of what it is. Mirwaldt et al. (2009) argue at a minimum there are four different definitions or components: 1) polycentric and endogenous development seeking to support the development of numerous competitive innovatory clusters across the European Union; 2) balanced development that reduces socioeconomic inequalities and imbalances across the European Union; 3) accessibility, in the sense that all European Union citizens should have access to the same basic level of services across the European Union where ever they live; and 4) a form of networking and connectivity between key centres across the European Union and between them and their hinterlands. Medeiros (2016, p. 7) also argues for the need "to concentrate the analysis on identifying the main dimensions and components of this concept." Thus, after an extensive review of different definitions, he argues for four key dimensions to the concept (Medeiros, 2016, $\mathrm{pp}, 10,15$, where he further elaborates on the 'component parts' of each dimension):

Territorial Cohesion is the process of promoting a more cohesive and balanced territory, by: (i) supporting the reduction of socioeconomic territorial imbalances; (ii) promoting environmental sustainability; (iii) reinforcing and improving the territorial cooperation/governance processes; and (iv) reinforcing and establishing a more polycentric urban system.

Whilst one can see some general characteristics that typify territorial cohesion the relationships and degree of primacy accorded to each is unclear and amounts to a 'list' of 'key issues.' As a result, there is considerable debate over what is/are the primary structuring factor(s) in these relationships and how they interact.

As Servillo (2010) argues the crux of the issue is the tension between competitiveness and the achievement of cohesion in its broadest sense. He notes:
The pursuit of economic growth through competition between territories and solidaristic attention to disparities between them are the two main oppositional positions against cohesive definitions of the European Union's institutional role, and both significantly affect the TC [Territorial Cohesion] concept. (p. 404)

The argument is that the competition discourse has becoming increasingly dominant in European Union discourse, particularly since the financial crash of $2007 / 2008$. Thus, the notion of territorial cohesion 'glosses over' the tensions between cohesion and competitiveness implying that the two can be reconciled through the place-based approach. While the turn to endogenous development and the argument that all places have strengths they can build on has obvious attractions, this ignores the fact the problems facing many places are deep seated and cannot be resolved at the local level or even with external support-many places are simply condemned by their past and cannot break out of it (i.e., a form of path dependency). This means there will inevitably be 'winners' and 'losers' and that this process runs the risk of intensifying territorial inequalities at pan-European, national and regional levels (cf. Atkinson, 2017, 2019).

\section{The Role of Spatial Configurations at Different Scales}

The European Union debate has tried to bring together the different dimensions of territorial cohesion and to internalise the spatial consequences of economic and social cohesion through different discursive constructs: One of those is the identification of specific spatial configurations, which can create the conditions for their integration in practice. This entails a focus on areas, places and spatial organisation patterns, rather than on sectors or policy domains, such as cohesion, agriculture, transport, environment, etc., in all the phases of policy design and implementation. The emphasis on place-based policies explicitly entered into the European debate following the Barca Report placing it at the centre of the discussion (Barca, 2009), but, as is well known, elements of the significance of the spatial dimension have been present in the debate since the mid-1990s.

Much of the European discourse on the role of space in European Union policy making from the late 1990s/beginning of the 2000s was focussed on spatial planning, and the attendant emphasis on how different policy domains and sectors could be integrated to support the objective of balanced and sustainable development across the European Union (see Atkinson \& Zimmermann, 2018). This perspective was/is controversial, both because the European Union does not have specific competences in the domain, and because it is derived from the very different traditions of spatial planning which historically characterise the different member states (Mirwaldt et al., 2009), and which have not exhibited any significant degree of convergence since 
the European Union approach emerged (Atkinson \& Zimmermann, 2018; Newman \& Thornley, 1996).

In order to better understand how certain influential spatial concepts contributed to frame the debate before and after the emergence and consolidation of the place-based approach, it is important to consider how the European Spatial Development Perspective introduced, defined and legitimised many concepts and discursive constructs that remain crucial to this day. This document highlights three 'complimentary' key objectives of European policy (as noted earlier): economic and social cohesion; conservation and management of natural resources and the cultural heritage; and a more balanced competitiveness of the European territory (Committee on Spatial Development, 1999), thus presenting itself as a "suitable policy framework for the sectoral policies of the Community and the member states that have spatial impacts" (Committee on Spatial Development, 1999).

The objective of the informal agreement between member states that led to the European Spatial Development Perspective was clearly to assess the possible spatial effects (in terms of adaptations of land use patterns and landscapes) of different sectoral policies and internalise them in policy design and policy making at different scales, understanding their potential overlaps, and to integrate spatial considerations into traditionally 'spatially-blind' policies, in order to better take into account geographical differences and a wide range of territorial disparities. The European Spatial Development Perspective, moreover, proposes to move one step ahead: There are a number of specific spatial configurations which are cited in the document that may potentially contribute to possible pathways towards the integration of the economic, social, and territorial dimensions of cohesion. These are recurring elements both in the debates that shaped the European Spatial Development Perspective (1999) and in the discourses that followed the delineation present in the document, e.g., in the Cohesion Reports and in some operational decisions, such as the creation of the European Spatial Planning Observation Network.

As the European Spatial Development Perspective states:

As early as 1994, the Ministers responsible for spatial planning agreed on three policy guidelines for the spatial development of the EU10: development of a balanced and polycentric urban system and a new urban-rural relationship; securing parity of access to infrastructure and knowledge; and sustainable development, prudent management and protection of nature and cultural heritage. (Committee on Spatial Development, 1991, p. 11)

The underlying assumption being that the general goal was to contribute to the definition of spatial development policies capable of promoting sustainable develop- ment of the European Union through the achievement of a balanced spatial structure. The first element is polycentricity, which in the European Union policy discourse is both a descriptive device and a normative notion; the European space it is argued has been (traditionally) polycentric, because it is based on a spatial and urban framework whose foundation has deep historical roots in the urbanisation of Europe. The argument is that in the face of the emergence of new spatial configurations, that in part reflect urbanisation in other parts of the world (North America, East Asia, the Global South), this space should continue to be polycentric, it should seek to maintain balanced polycentricity as these 'new spatial configurations' emerge (e.g., megacities and metropolitan regions). In this sense, polycentricity is understood as a pre-condition to fully utilise the economic potential of all European regions (an objective that became even more pressing after the enlargement of the European Union). The ultimate aim being to establish a 'virtuous circle' between the economic, social and territorial dimensions of cohesion: "The economic potential of all regions of the European Union can only be utilised through the further development of a more polycentric European settlement structure" (Committee on Spatial Development, 1999, p. 20). Yet even here we see that the emphasis is on the 'economic potential' rather than addressing social and territorial inequalities per se.

Secondly, in the European Spatial Development Perspective considerable attention is given to the urbanrural nexus, this should be strengthened with the aim to overcome the "outdated dualism between city and countryside" (Committee on Spatial Development, 1999, p. 19), through enhanced urban-rural relations. To an even greater extent than with polycentricity the approach is essentially a governance one, based on forms of cooperation across regions and administrative boundaries that include both urban and rural areas. It is argued there is a strong interdependence between them, even if this is not discussed in depth or really justified. Here the trans-scalar dimension, which is one of the crucial tenets of the European discourse on space, plays a key role, because the relations should be fostered at "a regional, supra-regional, interregional and transnational" level (Committee on Spatial Development, 1999, p. 26). The policy interventions proposed entail forms of integrated spatial planning, able to configure dense and complex urban/rural regions.

The third crucial element of spatial configuration, potentially able to link the different dimensions of cohesion, is the need to ensure accessibility to all European cities and regions, through the careful design of infrastructure networks able to structure territorial relations and to play a role in avoiding, or mitigating, the concentration of economies and opportunities in the most developed area at the centre of the European Union (i.e., the European Pentagon): "Promotion of integrated transport and communication concepts, which support the polycentric development of the European 
Union territory and are an important pre-condition for enabling European cities and regions to pursue their integration.... Regionally adapted solutions must be found for this" (Committee on Spatial Development, 1999, p. 20).

Finally, the European Spatial Development Perspective, and the ensuing debate, address the need to go beyond spatially-sensitive forms of policy coordination through experimentation with areabased programmes, or 'integrated spatial development approaches,' as they are called (Committee on Spatial Development, 1999, p. 19), such as INTERREG (Mirwaldt et al., 2009) or LEADER, pilot programmes, aimed at spatially defined areas (rural, trans-boundary, etc.). These programmes have played a double role in the European Union spatial planning discourse: They have been simultaneously considered test-beds, characterised by a certain degree of uniqueness, but, at the same time, they have been regarded as opportunities for mainstreaming some principles, policy elements and implementation tools, and are still considered in this way.

In addition to the above as noted earlier the placebased approach (Barca, 2009) has been closely associated with spatial planning and cohesion, as articulated in the Green Paper on Territorial Cohesion (Commission of the European Communities, 2008) and neo-endogenous development. This is part of more general approach often now referred to as territorial development (Cotella, Adams, \& Nunes, 2012; Faludi, 2015). However, it is important to bear in mind that the prevailing hegemonic discourse is one of neoliberalism, the aim being to improve Europe's competitiveness (see Olesen, 2014) particularly in the current period of economic crisis and fiscal austerity that exists across Europe (see Hermann, 2007, 2014). This is clearly expressed in the Green Paper on Territorial Cohesion (Commission of the European Communities, 2008), which argues:

Increasingly, competitiveness and prosperity depend on the capacity of the people and businesses located there to make the best use of all of territorial assets. In a globalising and interrelated world economy, however, competitiveness also depends on building links with other territories to ensure that common assets are used in a coordinated and sustainable way. Cooperation along with the flow of technology and ideas as well as goods, services and capital is becoming an ever more vital aspect of territorial development and a key factor underpinning the long-term and sustainable growth performance of the European Union as a whole. (p. 3)

This assumption is also embedded at the heart of Europe 2020 (Commission of the European Communities, 2010) in which the notions of smart, sustainable and inclusive growth are framed by the imperative to regain Europe's competitiveness or experience continued relative decline (Commission of the European Communities,
2010, pp. 8-9). Thus, there is a dissonance and tension between the competitiveness and cohesion dimensions of European Union policies, which is reflected in the approach to territorial development (see Servillo, 2010).

From this short overview, it emerges that even when discussing specifically spatial or territorial perspectives, there is an inherent circularity, because in the end they appear to be aimed at fostering and strengthening economic development and competitiveness. Thus, ultimately they function to support the competiveness of the European Union in the face of other regions of the world, thereby enabling governments, at different scales, to more effectively and fully mobilise diverse territorial assets in pursuit of enhanced competitiveness in the context of intensifying global competition. One final point needs to be reiterated: The European Spatial Development Perspective remains an intergovernmental document, which has no official status within the European Union.

\section{Intersections between Different Dimensions: The Italian Inner Areas Strategy}

As can be seen from the previous section, the intersections between the three dimensions of cohesion create uncertainties: Policy-wise there are trade-offs between the dimensions, nevertheless the economic one dominates. This approach assumes the territorial dimension (with the related concept of balanced development in the face of diversity) functions as a form of pre-requisite for the maximum deployment of the European Union's economic potential. Moreover, even if territorial cohesion is, in theory, a shared competence between the European Union and the member states, in fact it is a theoretical and strategic construct closely linked to the intervention of the European Commission, that finds little conceptualisation and application beyond the policy documents promoted by the Commission. Servillo recalls, in fact, how it is essentially a European discursive construct, which takes on meaning only if read with reference to other discursive chains of meaning, produced by the same actor and within the same decision-making networks (Servillo, 2010).

This aspect is particularly important when trying to understand the actual influence of this policy paradigm with respect to choices made at national or regional level. Individual member states understand and utilise this concept in different ways, and therefore the strategies they use to try and operationalise it are diverse and context specific. One interesting and debated policy experiment, that can be examined to better understand how different dimensions of cohesion interact to reframe the territorial cohesion concept, is the policy experimentation underway in Italy about inner areas. This policy is relevant to our argumentation because it provides a general framework for the spatialisation of Cohesion Policy, as it channels both European Union structural funds and national funding, following principles that attempt to overcome 
the longstanding North-South geographical divide which has been the main driver for territorial rebalancing policies in the country since the mid-20th century (Cotella \& Bovarone, 2020).

From the late 1990s, Cohesion Policy in Italy entered a phase called New Programming (Nuova Programmazione), an ambitious programme of extraordinary intervention in regions lagging behind, relying both on European Union structural funds (European Regional Development Fund, European Social Fund, and others) and on targeted domestic resources. This complex stream of interventions, based on innovative assumptions elaborated in the literature on local development over the previous twenty years, as well as on the tenets of New Public Management, emphasised the definition of bottom-up development strategies as a pre-requisite for accessing European Union funding channelled through regional programmes (Ministero del Tesoro, Bilancio e Programmazione Economica, 1998).

One widely diffused critique of this phase of policy experimentations has been about the ability to concentrate spending and investment in terms of both a territorial and thematic focus. This emerged throughout the different phases of Cohesion Policy, and it concerned both domestic and European Union resources (Palermo, 2009). Many initiatives and measures, such as Territorial Development Pacts or Territorial Integrated Projects, were originally devised as being focussed on crucial areas that could spark development in the wider region. The objective was to strategically target resources on more promising and complex projects, and/or territories in particular need, following Hirschman's idea of 'unbalanced growth' (Hirschman, 1958). However, in practice they were diffused over larger territories and populations, for reasons related to political clientelism.

One of the main results of the critical appraisal of the (mixed) outcomes of this phase can be found in the most recent developments of Italian national territorial cohesion policy, which led to a strong focus on Inner Areas: mountain areas, mainly located along the central axis of the country, and characterised by long standing processes of marginalisation. They are the object of a specific programme, launched by the Agency for Territorial Cohesion in 2012: The National Strategy for Inner Areas (Strategia Nazionale per le Aree Interne, SNAl; Agenzia per la Coesione Territoriale, 2013). Inner areas are characterised by the presence of a number of potentially generative elements that can make a relevant contribution to the development of the country, such as the presence of valuable landscapes, culture and local traditions. They require additional support for the construction of appropriate development policies, in order to fully develop their potential. Following the post-2007/2008 downturn they have exhibited increasingly visible evidence of abandonment, depopulation, presence of an ageing population and fragility of their agricultural production patterns (Pacchi, 2014). The recent earthquakes in Marche and Abruzzo intensified the need for such a strategy that could also offer a way to facilitate the reconstruction and re-development of the devastated areas. Given that the strategy provides a very clear attempt to rebalance and reduce the gaps with the most developed areas of the country (both metropolitan regions and medium density suburban areas), it can be seen to represent an interesting example of a policy aimed at territorial cohesion.

This policy strategy defines inner areas using two basic criteria, one explicitly spatial, which is accessibility, the other linked to the supply of public services. Areas that are characterised by both a low accessibility level and scarce supply of public services qualify as inner areas. Using these criteria, the relevant areas cover around $60 \%$ of the national territory, include $53 \%$ of municipalities and around $23 \%$ of the total Italian population.

The policy supports area-based projects working in selected development fields: land management and forests; local food products; renewable energy; natural and cultural heritage; traditional handicraft and SMEs. The explicit goal is territorial re-balancing through placebased projects. Inner areas are targeted because they potentially represent a significant asset for the country. However, at the moment, their resources are largely latent and underused, due to problems of abandonment, accessibility and to the fact that territorial and economic development policies have been concentrated on other parts of the country.

The policy area is the responsibility of the Agency for Territorial Cohesion (Agenzia per la Coesione Territoriale), a public body directly controlled by the Prime Ministers' Office, in charge of supporting national and European Union programming, but it is then based on a multilevel governance structure, that involves different institutional actors working strictly with local territories (this also includes the European Union, since the policy is also a vehicle used to implement European Regional Development Fund, European Social Fund and European Agricultural Fund for Rural Development funding, to municipalities). At local level the policy requires the construction of articulated, solid and durable partnerships, involving public and private actors, municipalities, local development agencies, service providers, firms and their representation bodies, and civil society organisations. The latter, in many cases, have a long (albeit not always successful) history of local cooperation, mainly in LEADER programmes. In this sense, there is a strong focus on territorial governance and forms of vertical and horizontal coordination, traditional tenets of territorial cohesion as expressed in European Union discourses, while, at the same time, there is an emphasis on the definition of place-specific policy measures. Such measures vary between areas, depending on the content of the agreements, which are defined at regional level with the representatives of each Inner Area, the concerned Region, and the National Agency for Territorial Cohesion.

While the Strategy is still on-going, there has been considerable debate about its effectiveness in tackling long standing problems in marginalised areas (Cotella \& 
Bovarone, 2020; Lucatelli \& Storti, 2019), as well as on the focus on this part of the country, rather than on other ones. There is a quite widespread agreement that, in general terms, the huge effort at tackling territorial imbalances through an explicitly territorialised policy strategy is an interesting one, which may take a considerable time to fully demonstrate its effects, since it is based on the pooling of dispersed knowledge and the use of external resources as incentives to trigger cooperation at local level. At the same time, more than in other areas, the risk of opportunistic behaviour on the part of local coalitions of rent-seeking interests, ultimately perpetuating forms of clientelism, is visible in many contexts.

If we look at the attempts to integrate the different dimensions of cohesion this approach requires, it is clear that governance arrangements play a crucial role in shaping the territorial dimension, while other, more substantive issues do not appear to be so relevant. Moreover, given the fragility and marginality of the areas under consideration, the integration of the three dimensions of cohesion appears to be an objective that can be achieved, if at all, in the long-term. In many local strategies the territorial and the social dimensions coincide to define local policies aiming, at best, to avoid the most negative consequences of on-going demographic and social infrastructure trends, rather than fully exploiting the potentials of a different economic development model. Thus, local inner areas policies tend to be limited to mitigation measures, rather than enhancing local competitiveness, which is one of the declared aims of the Inner Areas Strategy at national level. While we can see some evidence of an attempt to strive for 'balance' in terms of territorial development, there is little evidence of the deployment of polycentricity as an approach that might allow relevant centres to work together (or 'borrow size'; see Meijers \& Burger, 2015) to overcome their disadvantaged situation. Moreover, there is no clear identification of the relevant 'functional places' required by a placebased approach. Nor, at least to date, does the territorial governance dimension, required to 'knit' everything together, appear to have been fully realised.

\section{Conclusion: Territorial Cohesion: An Illusion Sacrificed on the Altar of Competitiveness}

As we have seen one of the few things those involved in the debate about territorial cohesion agree on is that it is closely tied to the notion of spatial planning/development (e.g., Davoudi, 2005; Faludi, 2009; Mirwaldt et al., 2009). More specifically the European Spatial Development Perspective has provided several of the key notions that constitute territorial cohesion. However, use of the term 'perspective' in its title implies a view (or an opinion) rather than a definitive statement. Thus, as with territorial cohesion, there is no clear, statement of what the European Spatial Development Perspective is. This means it is 'open to interpretation' and this is most clearly visible in relation to key con- cepts such as polycentricity and balanced and harmonious development. As a result, there is an inherent instability at the heart of the approach that has never been resolved and arguably cannot be resolved. This has implications for territorial cohesion and its relationship with economic and social cohesion. Without a clear and shared understanding of what the key notions mean there will be an endless process of debate and fuzziness over meanings and interrelations. This has been exacerbated by the increasing primacy of economic growth and competiveness particularly since the 2007/2008 crash. Indeed, as we noted in Section 2 at European level the attempt to integrate territorial, economic and social cohesion has largely been abandoned.

Following the Green Paper on Territorial Cohesion (Commission of the European Communities, 2008) and the Barca Report of 2009, in many ways the resolution of this conundrum was displaced to the national and subnational levels of member states. Here, by utilising a place-based approached focused on 'meaningful functional areas' pursuing a form of neo-endogenous local development based on the strengths of each area and addressing their problems, it was hoped a 'practical integration' could be achieved. Central to this 'practical integration' is the issue of developing new forms of (territorial) governance able to bring together a diverse range of stakeholders and resources and thereby to develop a long-term strategic and integrated approach.

In general terms this sounds eminently sensible. However, when we begin to interrogate key elements in these formulations, things become less clear. For instance, if we consider what is meant by integration this notion is open to dispute and uncertainty. In many cases integration rarely means more than 'sharing information.' Stead and Meijers (2009, p. 319) provide an insightful discussion of these issues, they highlight the confusion surrounding the notion of integration noting that "behind the rhetoric, a range of diverse meanings and manifestations of the concept can be found in policy documents." In terms of territorial cohesion clarity about the nature of integration is vital because, in policy terms, it is a central part of developing a holistic approach, including an appropriate governance framework, to the issue at whatever scale it is addressed. Unless we know what it is, we are seeking to integrate and why then the relationship to territorial cohesion becomes at best blurred and more realistically merely rhetoric. The result will be a continuation of the old fragmented sectoral approach dominated by local interests. This was amply illustrated in Section 4 where the (re)assertion of clientelism led to both the definition of 'target areas' and 'capture' of the policy. In this sense, we see here a possible tradeoff between proximity and focus: When cohesion policies are decided at the European Union or Member State level, there is the risk that the economic dimension overrides the others; on the other hand, when policies are defined at local level, the issues taken into account lead to more balanced outcomes, as in many cases within the 
Italian Inner Areas Strategy, but there is a higher risk of capture on the part of local interests.

Furthermore, the place-based approach itself is open to question. This notion of 'functional geography,' while somewhat vaguely defined, is to be understood in a multi-dimensional economic, social and cultural sense. However, defining 'functional places' is by no means a simple process. Servillo, Atkinson, and Hamdouch (2017) note there are considerable ontological problems when attempting to define what counts as a town and these apply to defining a 'functional place.' There are no easy and uncontested methods to identify the relevant spatial boundaries of these 'functional spaces' and the associated populations in a context constituted by variable 'spaces and flows' that create what Allmendinger and Haughton (2014, p. 20) call 'soft spaces' and fuzzy boundaries. Inevitably this requires 'choices' to be made concerning what constitutes the relevant 'functional places': Which flows should be included? Flows of people commuting for work (as measured by travel to work areas) or flows of goods and services? The selection of flows, or combination of flows, produces different 'functional places.' Furthermore, such places are supposed to be meaningful, this immediately raises the issue of 'meaningful in what sense' and to whom? Again Section 4 illustrates these issues in terms of how the relevant areas were defined. Here the definition was strongly influenced by political forces seeking to shape the direct policy to benefit their areas.

In addition to these general, some might argue abstract questions, there are more practical issues. In particular how to develop effective working and coordination relations that cross administrative boundaries. The Barca Report is aware of this issue and highlights the need to engage in institutional change if this approach is to be successful.

Moreover, if the multifaceted problems are to be addressed:

The intervention needed to tackle these problems should take the form of the provision of integrated bundles of public goods and services aimed at triggering institutional change, improving the well-being of people and the productivity of businesses and promoting innovation. The goods and services concerned need to be tailored to places by eliciting and aggregating local preferences and knowledge and by taking account of linkages with other places. (Barca, 2009, p. XI)

If such changes take place arrangements for citizen/community participation will need to be developed that bring together spatially and socially disparate groups to create 'deliberative fora' that can adequately represent their interests in policy development and implementation. Also, the long standing dilemma facing all such approaches remains: that the causes of many of the problems in a chosen space of intervention will not neces- sarily all be found within that space and are, at least in part, to be found in the wider regional, national and even supra-national context. It is not unreasonable to argue that no matter how well designed, integrated and coordinated these policies are they alone are unlikely to be able to resolve the problems facing a locality. Of course, the counter argument would be that this is precisely why integrated multilevel governance arrangements and actions are so important in order to combine exogenous and endogenous actions. Unfortunately, this has been inadequately followed through at European, national and subnational levels leaving the dissonance between territory and administrative unit largely intact (Commission of the European Communities, 2014, pp. 13-14; see also Atkinson, 2012; Servillo, 2010).

As we have seen there is no clear or definitive definition of territorial cohesion, it is both a theoretical concept and a political/normative programme. Indeed, it might be argued that the latter preceded the former and that the latter has in part sought to justify and amplify the former. It remains an inherently contested notion entwined with normative aspirations about the way in which the European space should be organised and experienced by its citizens. It is also intimately bound up with notions of European spatial planning/development, which is a way of achieving those aspirations. However, the problems associated with a notion that the European Union lacks a competence to engage in leaves a great deal in the hands of member states, some have sought to engage with this issue although by adapting it to complement their own national and regional agendas, which has produced a diverse range of responses.

Finally, and arguably most importantly, the dominance of the economic dimension and the overwhelming focus on improving the competitiveness and economic growth of the European Union and national economies means that the significance of territorial (and social) cohesion has been downgraded. In many instances even in terms of economic cohesion this has created intensified interregional inequalities, particularly in some member states in East Central Europe where the growth of national capitals and regional centres has intensified these inequalities. The ongoing impact of the Crash of $2007 / 2008$ has taken the form of fiscal austerity which has been framed by the neoliberal assumption that market failure did not cause these problems but, rather, that the economic crisis resulted from state intervention in market processes and excessive fiscal expenditure by the state-thus the need for fiscal austerity. The result has been a hegemonic consensus that has internalised neoliberal articles of faith, thus as Olesen (2014, p. 8) argued ideas such as "economic growth and competitiveness are being normalised as commonsense policy objectives." These assumptions are seen as 'unquestionable' - they are presented as the only 'solutions' to the crisis. In this context it is little wonder that the search for territorial (and social and economic) cohesion has, in effect, been abandoned. 


\section{Acknowledgments}

The research on which this article is based has been funded through the 'Horizon 2020: The Framework Programme for Research and Innovation (2014-2020)' COHSMO Project, under Grant agreement No 727058. The views expressed in this article are those of the authors and do not necessarily reflect those of the funding organisation or the COHSMO consortium.

\section{Conflict of Interests}

The authors declare no conflict of interests.

\section{References}

Agenzia per la Coesione Territoriale. (2013). Strategia nazionale per le Aree interne: Definizione, obiettivi, strumenti e governance (Documento tecnico collegato alla bozza di Accordo di Partenariato trasmessa alla CE il 9 dicembre 2013) [National strategy for internal areas: Definition, objectives, tools and governance (Technical document linked to the draft Partnership Agreement sent to the European Commission on 9 December 2013)]. Rome: Agenzia per la Coesione Territoriale.

Allmendinger, P., \& Haughton, G. (2014). The evolution and trajectories of English spatial governance: 'Neoliberal' episodes in planning. Planning Practice \& Research, 28(1), 6-26.

Atkinson, R. (1999). Discourses of partnership and empowerment in contemporary British urban regeneration. Urban Studies, 36, 59-72.

Atkinson, R. (2000). Narratives of the inner city: The construction of urban problems and urban policy in the official discourse of British government, 1968-1998. Critical Social Policy, 20(2), 211-232.

Atkinson, R. (2001). The emerging 'urban agenda' and the European spatial development perspective: Towards and European Union urban policy? European Planning Studies, 9(3), 385-406.

Atkinson, R. (2012). Contemporary urban governance and the search for competitiveness: Mobilisation of assets in the bid to improve 'urban attractiveness. In A. P. Marques \& R. Moreira (Eds.), Governação e territorialidades: Lógicas e práticas na administração local [Governance and territorialities: Logics and practices in local administration] (pp. 23-46). Braga: Universidade do Minho.

Atkinson, R. (2017). Policies for small and mediumsized towns: European, national and local approaches. Tijdschrift voor Economische en Sociale Geografie, 108(4), 472-487.

Atkinson, R. (2019). The small towns conundrum: What do we do about them? Regional Statistics, 9(2), 1-17.

Atkinson, R., \& Zimmermann, K. (2018). European spatial planning policy. In H. Heinelt \& S. Münch (Eds.), Handbook of European policy: Interpretive approach- es to the European Union (pp. 156-172). Cheltenham: Edward Elgar Publishing.

Barca, F. (2009). An agenda for a reformed cohesion policy: A place-based approach to meeting European Union challenges and expectations. Brussels: European Commission.

Colomb, C., \& Santinha, G. (2014). European Union competition policy and the European territorial cohesion agenda: An impossible reconciliation? State aid rules and public service liberalization through the European spatial planning lens. European Planning Studies, 22(3), 459-480.

Commission of the European Communities. (2005). Third progress report on cohesion: Towards a new partnership for growth, jobs and cohesion, Communication from the Commission. Brussels: European Commission.

Commission of the European Communities. (2008). Green Paper on territorial cohesion: Turning territorial diversity into strength. Luxembourg: Office for Official Publications of the European Communities.

Commission of the European Communities. (2010). Europe 2020. A strategy for smart, sustainable and inclusive growth. Luxembourg: Office for Official Publications of the European Communities.

Commission of the European Communities. (2014). Investment for jobs and growth. Promoting development and good governance in EU Regions and cities. Sixth report on economic, social and territorial cohesion. Brussels: Directorate-General for Regional and Urban Policy.

Commission of the European Communities. (2017). Seventh report on economic, social and territorial cohesion: My region, my Europe, our future. Brussels: Directorate-General for Regional and Urban Policy.

Committee on Spatial Development. (1999). European spatial development perspective: Towards balanced and sustainable development of the territory of the European Union. Brussels: Committee on Spatial Development.

Consolidated version of the Treaty on the Functioning of the European Union, 2012/C 326/01 (2012).

Cotella, G., Adams, N., \& Nunes R. J. (2012). Engaging in European spatial planning: A central and eastern European perspective on the territorial cohesion debate. European Planning Studies, 20(7), 1-24.

Cotella, G., \& Bovarone, V. (2020). The Italian national strategy for inner areas: A place-based approach to regional development. In J. Bański (Ed.), Dilemmas of regional and local development (pp. 1-29). London: Routledge.

Davoudi, S. (2005). Understanding territorial cohesion. Planning, Practice \& Research, 20(4), 433-441.

European Commission. (2015) Territorial Agenda 2020 put in practice. Enhancing the efficiency and effectiveness of cohesion policy by a place-based approach. Brussels: European Commission.

Faludi, A. (2009). A turning point in the development 
of European spatial planning? The 'Territorial Agenda of the European Union' and the 'First Action Programme.' Progress in Planning, 71, 1-42.

Faludi, A. (2015). Place is a no-man's land. Geographia Polonica, 88(1), 5-20.

Hall, S. (1997). The work of representation. In S. Hall (Ed.), Representation: Cultural representations and signifying practices (pp. 133-174). London: Sage.

Hermann, C. (2007). Neoliberalism in the European Union. Studies in Political Economy, 79, 61-89.

Hermann, C. (2014). Structural adjustment and neoliberal convergence in labour markets and welfare: The impact of the crisis and austerity measures on European economic and social models. Competition \& Change, 18(2), 111-130.

Hirschman, A. O. (1958). The strategy of economic development. New Haven, CT: Yale University Press.

Lucatelli, S., \& Storti, D. (2019). La strategia nazionale aree interne e lo sviluppo rurale: Scelte operate e criticità incontrate [The national strategy for inner areas and rural development: Choices made and criticalities encountered]. Agriregionieuropa.

Medeiros, E. (2016). Territorial cohesion: A European Union concept. European Journal of Spatial Development, 60, 1-30.

Meijers, E. J., \& Burger, M. J. (2015). Stretching the concept of 'borrowed size.' Urban Studies, 54(1), 1-23. https://doi.org/10.1177/0042098015597642

Ministero del Tesoro, Bilancio e Programmazione Economica. (1998). La nuova programmazione e il Mezzogiorno. Orientamenti per l'azione di governo [The new programming and the South. Directions for government action]. Roma: Donzelli.

Mirwaldt, K., McMaster, I., \& Bachtler, J. (2009). Reconsidering cohesion policy: The contested debate on territorial cohesion (European Policy Research Paper No. 66). Glasgow: University of Strathclyde.

Newman, P. W. G., \& Thornley, A. (1996). Urban planning in Europe: International competition, national systems, and planning projects. East Sussex: Psychology Press.
Olesen, K. (2014). The neoliberalisation of strategic spatial planning. Planning Theory, 13(3), 288-303.

Pacchi, C. (2014). The role of cities within the new European programming: Interview with Fabrizio Barca. Urbanistica, 152, 11-16.

Palermo, P. C. (2009). I limiti del possibile. Governo del territorio e qualità dello sviluppo [The limits of what is possible. Territorial governance and quality of development]. Rome: Donzelli.

Radaelli, C. (2004). Europeanisation: Solution or problem? European Integration Online Papers, 8(16), 1-23.

Servillo, L. (2010). Territorial cohesion discourses: Hegemonic strategic concepts in European spatial planning. Planning Theory and Practice, 11(3), 397-416.

Servillo, L., Atkinson, R., \& Hamdouch, A. (2017). Small and medium-sized town in Europe: Conceptual and methodological approaches. Tijdschrift voor Economische en Sociale Geografie, 108(4), 356-379.

Stead, D., \& Meijers, E. (2009). Spatial planning and policy integration: Concepts, facilitators and inhibitors. Planning Theory and Practice, 10(3), 317-332.

Territorial Agenda of the European Union. (2007). Territorial agenda of the European Union: Towards a more competitive and sustainable Europe of diverse regions. Federal Ministry of Transport and Digital Infrastructure. Retrieved from https://ec.europa.eu/ regional_policy/en/information/publications/ communications/2007/territorial-agenda-of-theeuropean-union-towards-a-more-competitive-andsustainable-europe-of-diverse-regions

Territorial Agenda of the European Union. (2011). Territorial agenda of the European Union 2020: Towards an inclusive, smart and sustainable Europe of diverse regions. Brussels: European Union. Retrieved from http://www.eu2011.hu/files/bveu/documents/ TA2020.pdf

Zaucha, J. (2015). Key dimensions of territorial cohesion: A review of the existing sources of information on the territorial cohesion (Working Paper No. 008/2015). Sopot: Instytut Rozwoju Institute for Development Working Papers.

\section{About the Authors}

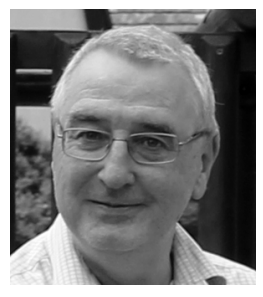

Rob Atkinson is a Professor at the University of the West of England, Bristol, in the Department of Geography and Environmental Management, he is also a Member of the Centre for Sustainable Planning and Environments. His research interests include cross-national work on urban regeneration, urban governance and community participation, urban social exclusion and European urban and spatial policy and published widely on these areas. A key transversal aspect of this work has been a concern with sustainability and the nature of sustainable urban development. In parallel, and closely linked, he has also become increasingly interested in the role of knowledge and how different forms of knowledge are combined with particular reference to urban and spatial policies/projects. He has participated in a wide range of pan-European research projects. He is Editor of the journal Urban Research and Practice. 


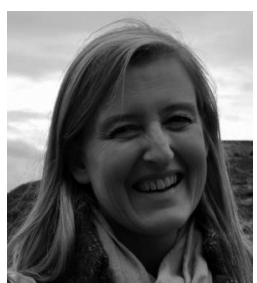

Carolina Pacchi is an Associate Professor at the Politecnico di Milano, where she teaches Planning Theory and Practice and Local Conflict Resolution and is part of the Polimi2040 Roundtable on future strategies for technical education. She has done research on the transformation of urban governance in European cities, and on forms of alternative politics and grassroots activism at local level. She has been involved in a number of European Union funded research projects on governance in urban, environmental and local development policies. 